\title{
Evaluation of the chemical and sensory attributes of juice developed from cashew and jackfruit pulp
}

\author{
"Okudu, HO and Onyendi, SU
}

Department of Human Nutrition and Dietetics Michael Okpara University of Agriculture Umudike, Abia State ${ }^{*}$ Corresponding Author Email: helenokudu@yahoo.com and Tel: +2340869189948.

\section{ABSTRACT}

\begin{abstract}
Ready to eat Jackfruits (Artocarpus heterophyllus) were harvested from Obingwa and Ubakala in Abia state; the cashew apples (Anacardium occidentale) were harvested from cashew plantation along Enugu-Port Harcourt road, Enugu state, Nigeria. Standard method was used to prepare the juices and their blends. The proximate and vitamin content of the samples were determined using standard AOAC methods. Mineral elements were determined using wet-acid digestion method for multiple nutrients determination. All tests were carried out in duplicates and the data generated were analysed using standard methods. The moisture content of jackfruit juice, cashew juice and their blends ranges from $90.6 \%$ to $92.2 \%$, with cashew juice having the highest moisture $(92.2 \%)$ value While, jackfruit juice had the least moisture value $(90.6 \%)$. Crude protein, ash and total carbohydrate values $(1.32 \%, 0.46 \%$, and $7.06 \%$ respectively) were significantly higher in jackfruit juice. Energy values of the products ranged between $29 \mathrm{kcal}$ to $38 \mathrm{kcal}$. Iron was generally low in all the products. Cashew juice is a richer source of vitamins $\beta$-carotene, vitamin $C$ and vitamin $E(2.35 \mathrm{mcg} / 100 \mathrm{~g}, 284.35 \mathrm{mg} / 100 \mathrm{~g}$ and $0.47 \mathrm{mg} / 100 \mathrm{~g}$ respectively), followed by cashew juice: jackfruit juice $(70: 30)$ blend $(2.05 \mathrm{mcg} / 100 \mathrm{~g}, 234.54 \mathrm{mg} / 100 \mathrm{~g})$ and $0.42 \mathrm{mgmg} / 100 \mathrm{~g}$ respectively). Vitamins $C$ and $E$ ranged between $125-284 \mathrm{mg} / 100 \mathrm{~g} .0 .38-0.49 \mathrm{mg} / 100 \mathrm{~g}$ respectively; with cashew juice having the highest vitamin $C$ and $E$ values $(284 \mathrm{mg} / 100 \mathrm{~g}, 0.49 \mathrm{mg} / 100 \mathrm{~g}$ respectively). The major components of the products were moisture, carbohydrate and protein. It was noted that jackfruit juice added to cashew juice at different proportions increased the magnesium and iron values of the blends, but reduced the sodium values. The result also showed that making blends from cashew and jackfruit juices enhances acceptability of the products.
\end{abstract}

Keywords: Jackfruit, Cashew, Pulp, Form, Intake

\section{INTRODUCTION}

Fruits, vegetables and nuts are known for their significant roles in human nutrition (Craig and Beck, 1999; Wargorich, 2000). Aside the fact that they are cheap sources of vitamins and minerals they are also good sources of phytochemicals (Liu, 2003). Phytochemicals are plant chemicals that are associated with of health benefits (Wargorich, 2000); this could be the reason the United States Dietary Allowance (USDA, 2000) encourages consumers to eat at least 2 servings of fruits, and at least 3 servings of vegetables each day. Studies carried out in various locations in Nigeria, however showed that most people in Nigeria do not consume the required amounts of fruits and vegetables per day (Hart et al., 2007; Williams et al., 2009). The shortfall in the consumption of fruits and vegetables in Nigeria are attributed to many factors. Among them are the facts that fruits and vegetables are expensive and are beyond the reach of poor households (Pallock, 2001). Taboos and cultural beliefs also play significant roles in many populations, especially for selected physiological or age group, such as pregnant women and lactating women and young infants (Pallock, 2001). Mangos for example are believed to cause diarrhea in young children in many cultures, and therefore intake of this excellent sources of vitamin $A$ by young children who are at highest risk of vitamin A deficiency is often contracted (Pollack, 2001). Another factor that could be responsible for the shortfall in consumption of fruits and vegetables are the forms in which they are served.

Jackfruit (Artocarpus heterophyllus) is the largest fruit in the world (Haque, 2010), with a few species weighing almost 50kg. Jackfruit grows abundantly in Bangladesh, India, and in many parts of South East Asia (Rahman et al., 1999; Eke-Ejiofor and Owuno, 2013); it is also 
cultivated in some countries in West Africa, Nigeria inclusive (Burkill, 1997). Nutritionally, jackfruit pulp is said to be rich in vitamins and minerals, but low in caloric value (Samaddar, 1985; Mukprasirt and Sajaanantakul, 2004).

Cashew apple (sometimes called Pseudocarp of false fruit) is an oval or pear-shaped structure that develops from the pedicel or receptacle of the cashew flower. It ripens into a yellow and red structure of about $5-11 \mathrm{~cm}$ long; it is edible and has a strong smell and a sweet taste (Pillai and Santha, 2008). Cashew apple is a valuable source of minerals and vitamins (Akinwale, 2000).

Jackfruit and cashew pulp are majorly consumed fresh in Nigeria; there is therefore need to diversify the forms in which they are normally consumed in other to increase intake. This work was designed to develop and chemically analyse juice and blends made from jackfruit and cashew pulps.

\section{MATERIALS AND METHODS}

\section{Sources of raw materials}

Ready to eat Jackfruits (Artocarpus heterophyllus) were harvested from Obingwa and Ubakala in Abia state. Fresh cashew apples (Anacardium occidentale) were harvested from cashew plantation along Enugu-Port Harcourt road, Enugu state, Nigeria.

\section{Juice preparation/extraction}

The fruits were washed thoroughly with potable water. The jackfruits were cut open and the seed extracted manually. The edible portions of the jackfruit and cashew were cut into thin slices using kitchen knife. Jackfruit and cashew pulps were blended separately using an electric blender model LB20E Torrington, USA. The blends were screened through double-folded muslin cloth.

\section{Blending of juices}

The jackfruit was used to replace 30,50 and $70 \%$ of the cashew juice. The mixtures were then blended in an electric blender (Model LB20E) operated a full speed for 3 minutes. The juices and their blends were pasteurized in a water bath at $70^{\circ} \mathrm{C}$ for 20 minutes. The juices were then poured into sterile sample bottles and taken immediately for analysis.

\section{Chemical analyses}

The proximate compositions of the sample were determined using standard A.O.A.C. (2006) methods. Moisture content of the juice was determined gravimetrically. The crude protein content was determined by micro-Kjeldahl method, using 6.25 as the nitrogen conversion factor. The crude fat content was determined by Soxhlet extraction method using petroleum ether. The ash content was determined by incinerating the samples at $600^{\circ} \mathrm{C}$ in a muffle furnace. Carbohydrate was obtained by difference, while energy was calculated using the Atwater Conversion factors in $\mathrm{KJ}$ and $\mathrm{Kcal}(17 \mathrm{KJ} / 4 \mathrm{Kcal}, 17 \mathrm{KJ} / 4 \mathrm{Kcal}$, and $37 \mathrm{KJ} / 9 \mathrm{Kcal}$, for protein, carbohydrate and lipid respectively.

Mineral elements were determined using wet-acid digestion method for multiple nutrients determination as described by the method of A.O.A.C (2006). About $0.2 \mathrm{~g}$ of the processed sample material was weighed into a $150 \mathrm{ml}$ Pyrex conical flask. Five (5.0) $\mathrm{ml}$ of the extracting mixture $\left(\mathrm{H}_{2} \mathrm{SO}_{4}\right.$ - Sodium Salicylic acid) was added to the sample. The mixture was allowed to stand for 16 hours. The mixture was then placed on a hot plate set at $30^{\circ} \mathrm{C}$ and allowed to heat for about 2hours. Five (5.0) $\mathrm{ml}$ of concentrated perchloric acid was introduced to the sample and heated vigorously until the sample was digested to a clear solution. Twenty (20) milliliters of distilled $\mathrm{H} 2 \mathrm{O}$ was added and heated to mix thoroughly for about a minute. The digest was allowed to cool and was transferred into a $50 \mathrm{ml}$ volumetric flask and made up to the mark with distilled water. The digest was used for the determinations of calcium $(\mathrm{Ca})$ and magnesium $(\mathrm{Mg})$ by the ethylamine ditetra acetic acid (EDTA) versanate complexiometric titration method. Potassium (K) and sodium $(\mathrm{Na})$ were evaluated by flame photometry method and phosphorus $(P)$ by the vanadomolybdate method using the spectrophotometer. The trace metals (zinc, iron, copper, selenium, manganese and iodine) were determined using the atomic absorption spectrophotometer 969 instrument. The appropriate cathode lamp was fixed for each element. The sample was introduced to the atomizer and the value concentration of the element printed out as $\mathrm{mgX} /$ liter.

The $\beta$-carotene, riboflavin, niacin and thiamin of the products were determined spectrophotometrically as described by AOAC (2006). While ascorbic acid was determined as described by AOAC (2006) using titration method. Gravimetric method (Harborne, 1973) was used to determine alkaloids. Saponin was determined by gravimetric oven drying method as described by the method of A.O.A.C (2006). Tannin content of the sample was determined spectrophometrically as described by Kirk and Sawyer (1991). Phenol was determined by the folin-ciocatean spectrophotometry method (AOAC 2006). Flavonoid was determined by gravimetric oven drying method as described by Harborne (1973).

\section{Statistical analysis}

All determinations were done in duplicates. The data generated were entered into the computer and analyzed using Statistical Package for Social Sciences (SPSS 
096 Afr. J. Food Sci. Technol.

Table 1.Energy and proximate composition of juice developed from jackfruit, cashew pulp and those of their blends.

\begin{tabular}{|c|c|c|c|c|c|c|}
\hline Sample & Moisture (\%) & $\begin{array}{l}\text { Crude protein } \\
(\%)\end{array}$ & $\begin{array}{l}\text { Crude fat } \\
(\%)\end{array}$ & $\begin{array}{l}\text { Ash } \\
(\%)\end{array}$ & $\begin{array}{l}\text { Carbohydrate } \\
(\%)\end{array}$ & $\begin{array}{l}\text { Energy } \\
\text { (kcal/kj) }\end{array}$ \\
\hline $100 \%$ cashew juice & $92.9^{a} \pm 0.28$ & $1.08^{\mathrm{d}} \pm 0.02$ & $0.74^{a} \pm 0.00$ & $0.21^{\mathrm{e}} \pm 0.01$ & $4.1^{\mathrm{d}} \pm 0.01$ & $27 / 115$ \\
\hline $100 \%$ jackfruit juice & $90.6^{d} \pm 0.01$ & $1.32^{\mathrm{a}} \pm 0.03$ & $0.58^{\mathrm{C}} \pm 0.00$ & $0.46^{a} \pm 0.00$ & $7.1^{a} \pm 0.00$ & $38 / 164$ \\
\hline $50 \% \mathrm{~J}: 50 \% \mathrm{C}$ & $91.8^{\mathrm{C}} \pm 0.01$ & $1.14^{\mathrm{C}} \pm 0.01$ & $0.64^{b} \pm 0.03$ & $0.38^{b} \pm 0.00$ & $6.0^{\mathrm{b}} \pm 0.57$ & $34 / 145$ \\
\hline $70 \% \mathrm{~J}: 30 \% \mathrm{C}$ & $91.8^{\mathrm{C}} \pm 0.00$ & $1.22^{\mathrm{b}} \pm 0.00$ & $0.66^{b} \pm 0.01$ & $0.34^{c} \pm 0.02$ & $5.9^{b} \pm 0.01$ & $34 / 146$ \\
\hline $30 \% \mathrm{~J}: 70 \% \mathrm{C}$ & $92.1^{c} \pm 0.01$ & $1.09^{d} \pm 0.14$ & $0.71^{\mathrm{a}} \pm 0.01$ & $0.29^{d} \pm 0.00$ & $5.8^{\mathrm{C}} \pm 0.05$ & $33 / 142$ \\
\hline
\end{tabular}

Values with the same superscript on the same column are not significantly different $(p>0.05)$ from each other. 50\%J:50\%C=50\%jackfruit juice:50\%cashew juice; 70\%J:30\%C=70\%jackfruit juice:30\%cashew juice; 30\% J:70\%C=30\%jackfruit juice: $70 \%$ cashew juice

Table 2. Mineral composition of juice developed from jackfruit, cashew pulp and those of their blends.

\begin{tabular}{lllll}
\hline Sample & Calcium & Magnesium & Sodium & Iron \\
\hline $\mathbf{1 0 0 \% c a s h e w ~ j u i c e ~}$ & $80.10^{\mathrm{a}} \pm 0.08$ & $28.55^{\mathrm{e}} \pm 0.01$ & $9.61^{\mathrm{a}} \pm 0.42$ & $0.25^{\mathrm{e}} \pm 0.01$ \\
$\mathbf{1 0 0 \%}$ jackfruit juice & $34.21^{\mathrm{e}} \pm \pm 0.02$ & $108.30^{\mathrm{a}} \pm 0.22$ & $6.22^{\mathrm{e}} \pm 0.64$ & $0.62^{\mathrm{a}} \pm 0.03$ \\
$\mathbf{5 0 \% J : 5 0 \% C}$ & $5729^{\mathrm{c}} \pm 0.05$ & $63.76^{\mathrm{c}} \pm 0.64$ & $7.34^{\mathrm{c}} \pm 0.05$ & $0.44^{\mathrm{c}} \pm 0.02$ \\
$\mathbf{7 0 \% J : 3 0 \% C}$ & $46.17^{\mathrm{d}} \pm 0.05$ & $101.15^{\mathrm{b}} \pm 0.27$ & $6.95^{\mathrm{d}} \pm 0.04$ & $0.53^{\mathrm{b}} \pm 0.01$ \\
$\mathbf{3 0 \% J : 7 0 \% C}$ & $64.38^{\mathrm{b}} \pm 0.05$ & $50.42^{\mathrm{d}} \pm 0.01$ & $8.08^{\mathrm{b}} \pm 0.50$ & $0.34^{\mathrm{d}} \pm 0.01$
\end{tabular}

Values with the same superscript on the same column are not significantly different $(p>0.05)$ from each other. 50\%J:50\%C=50\%jackfruit juice:50\%cashew juice; $70 \% \mathrm{~J}: 30 \% \mathrm{C}=70 \%$ jackfruit juice:30\%cashew juice; $30 \% \mathrm{~J}: 70 \% \mathrm{C}=30 \%$ jackfruit juice:70\%cashew juice

version 16.0) Means and standard deviation obtained from the chemical analysis were calculated. Level of significance was accepted at $p<0.05$.

\section{RESULTS}

Energy and proximate composition of jackfruit, cashew juice and those of their blends

The energy and proximate composition of jackfruit, cashew juice and those of their blends is shown on Table 1. The moisture contents of the products ranged from $90.6 \%$ to $92.2 \%$. Cashew juice had the highest moisture $(92.2 \%)$ value, while jackfruit juice had the least moisture value $(90.6 \%)$. Crude protein, ash and total carbohydrate $(1.32 \%, 0.46 \%, 7.06 \%$ respectively) were found to be significantly higher in $100 \%$ jackfruit juice, while crude fat value was found to be higher in $100 \%$ cashew juice $(0.74 \%)$ and cashew: jackfruit $(70: 30)(0.71 \%)$. Energy values of the products ranged between $29.38 \mathrm{kcal}$ to $38.74 \mathrm{kcal}$, with $100 \%$ jackfruit juice having the highest energy value (38.74kcal) and $100 \%$ cashew juice the least.

\section{Mineral composition of jackfruit, cashew juice and their blends}

The mineral composition of juice developed from jackfruit, cashew and those of their blends is shown on Table 2. Calcium and sodium values were significantly higher in cashew juice $(80.1 \mathrm{mg} / 100 \mathrm{~g} ; 9.6 \mathrm{mg} / 100 \mathrm{~g}$ respectively), while magnesium and iron were significantly higher in $100 \%$ jackfruit juice $(108.3 \mathrm{mg} / 100 \mathrm{~g} ; \quad 0.63 \mathrm{ng} / 100 \mathrm{~g}$ respectively).

\section{Vitamin composition of jackfruit, cashew juice and their blends}

The result of vitamins on Table 3 showed that $\beta$-carotene ranged between $1.63 \mathrm{mcg} / 100 \mathrm{~g}-2.35 \mathrm{mcg} / 100 \mathrm{~g}$. Cashew juice is a richer source of vitamins $\beta$-carotene, vitamin $C$ and vitamin E $(2.35 \mathrm{mcg} / 100 \mathrm{~g}, 284.35 \mathrm{mg} / 100 \mathrm{~g}$, $0.47 \mathrm{mg} / 100 \mathrm{~g}$ respectively), followed by $70: 30$ 
Table 3. Vitamin composition of juice developed from jackfruit, cashew pulp and those of their blends.

\begin{tabular}{|c|c|c|c|}
\hline Sample & $\begin{array}{l}\beta \text {-carotene } \\
\mathrm{mcg} / 100 \mathrm{~g}\end{array}$ & $\begin{array}{l}\text { Vitamin C } \\
\mathrm{mg} / 100 \mathrm{~g}\end{array}$ & $\begin{array}{l}\text { Vitamin E } \\
\mathrm{mg} / 100 \mathrm{~g}\end{array}$ \\
\hline $100 \%$ cashew juice & $2.35 \pm 0.01$ & $284.35^{a} \pm 0.21$ & $0.47^{\mathrm{a}} \pm 0.01$ \\
\hline $100 \%$ jackfruit juice & $1.63 \pm 0.01$ & $125.67^{e} \pm 0.16$ & $0.34^{\mathrm{e}} \pm 0.00$ \\
\hline $50 \% \mathrm{~J}: 50 \% \mathrm{C}$ & $1.88 \pm 0.01$ & $201.37^{\mathrm{C}} \pm 0.11$ & $0.36^{\mathrm{d}} \pm 0.00$ \\
\hline $70 \% \mathrm{~J}: 30 \% \mathrm{C}$ & $1.76 \pm 0.04$ & $178.50^{d} \pm 0.04$ & $0.39^{c} \pm 0.01$ \\
\hline $30 \% \mathrm{~J}: 70 \% \mathrm{C}$ & $2.05 \pm 0.01$ & $234.54^{\mathrm{b}} \pm 0.26$ & $0.42^{\mathrm{b}} \pm 0.00$ \\
\hline
\end{tabular}

Values with the same superscript on the same column are not significantly different $(p>0.05)$ from each other. $50 \% \mathrm{~J}: 50 \% \mathrm{C}=50 \%$ jackfruit juice:50\%cashew juice;70\%J:30\%C=70\%jackfruit juice:30\%cashew juice; $30 \% \mathrm{~J}: 70 \% \mathrm{C}=30 \%$ jackfruit juice: $70 \%$ cashew juice.

Table 4. Antinutrient composition of juice developed from jackfruit, cashew pulp and those of their blends.

\begin{tabular}{|c|c|c|c|}
\hline Sample & Phytate & Tannin & Alkaloid \\
\hline $100 \%$ cashew juice & $0.43^{\mathrm{e}} \pm 0.01$ & $0.52^{\mathrm{a}} \pm 0.00$ & $0.16^{\mathrm{C}} \pm 0.00$ \\
\hline $100 \%$ jackfruit juice & $0.54^{\mathrm{a}} \pm 0.02$ & $0.47^{e} \pm 0.01$ & $0.22^{\mathrm{a}} \pm 0.01$ \\
\hline $50 \% \mathrm{~J}: 50 \% \mathrm{C}$ & $0.49^{c} \pm 0.01$ & $0.49^{c} \pm 0.00$ & $0.19^{\mathrm{b}} \pm 0.01$ \\
\hline $70 \% \mathrm{~J}: 30 \% \mathrm{C}$ & $0.51^{\mathrm{b}} \pm 0.01$ & $0.48^{d} \pm 0.00$ & $0.19^{b} \pm 0.00$ \\
\hline $30 \% \mathrm{~J}: 70 \% \mathrm{C}$ & $0.46^{d} \pm 0.01$ & $0.51^{\mathrm{b}} \pm 0.01$ & $0.18^{b} \pm 0.01$ \\
\hline
\end{tabular}

Values with the same superscript on the same column are not significantly different ( $p>0.05$ ) from each other. $50 \% \mathrm{~J}: 50 \% \mathrm{C}=50 \%$ jackfruit juice: 50\%cashew juice; $70 \% \mathrm{~J}: 30 \% \mathrm{C}=70 \%$ jackfruit juice:30\%cashew juice; $30 \% \mathrm{~J}: 70 \% \mathrm{C}=30 \%$ jackfruit juice: $70 \%$ cashew juice

(cashew:jackfruit) blend $(2.05 \mathrm{mcg} / 100 \mathrm{~g}, \quad 234.54$ $\mathrm{mg} / 100 \mathrm{~g}), 0.42 \mathrm{mgmg} / 100 \mathrm{~g}$ respectively).

\section{The antinutrient composition of juice developed from jackfruit and cashew pulp and their blends}

The antinutrient composition of the products of Table 4 showed that jackfruit juice had the highest phytate and alkaloid values $(0.54 \mathrm{mg} / 100 \mathrm{~g} ; \quad 0.22 \mathrm{mg} / 100 \mathrm{~g}$ respectively), while cashew juice had the highest tannin value $(0.52 \mathrm{mg} / 100 \mathrm{~g})$.

\section{The sensory attributes of juice developed from jackfruit and cashew pulp and their blends}

The sensory attributes of the products are shown on Table 5 . The result showed that $100 \%$ cashew juice had the highest value for colour (6.15), while taste value (4.45) for jackfruit: cashew (30:70) juice and flavor value (4.50) for jackfruit: cashew (50:50) juice were comparable to the taste and flavor values of $100 \%$ cashew juice (5.25, 5.05 respectively). In terms of general acceptability, $100 \%$ cashew juice and jackfruit: cashew (70:30) juice were generally more acceptable than the jackfruit: cashew (50:50) juice jackfruit: cashew (30:70) juice.

\section{DISCUSSION}

The energy and proximate composition of jackfruit juice, cashew juice and those of their blends are presented in Table 1. The major components of the products were moisture, carbohydrate and protein. The moisture value 
098 Afr. J. Food Sci. Technol.

Table 5. Sensory attributes of juice developed from jackfruit, cashew pulp and those of their blends.

\begin{tabular}{lllll}
\hline Sample & Colour & Taste & Flavour & General acceptability \\
\hline $\mathbf{1 0 0} \%$ cashew juice & $6.15^{\mathrm{a}} \pm 0.67$ & $5.25^{\mathrm{a}} \pm 0.91$ & $5.05^{\mathrm{a}} \pm 1.23$ & $5.25^{\mathrm{a}} \pm 0.97$ \\
$\mathbf{1 0 0 \%}$ jackfruit juice & $5.10^{\mathrm{b}} \pm 1.83$ & $4.40^{\mathrm{b}} \pm 1.79$ & $4.15^{\mathrm{c}} \pm 1.76$ & $4.55^{\mathrm{b}} \pm 1.61$ \\
$\mathbf{5 0 \% J : 5 0 \% C}$ & $4.75^{\mathrm{b}} \pm 1.08$ & $4.25^{\mathrm{c}} \pm 1.65$ & $4.50^{\mathrm{a}} \pm 1.85$ & $4.40^{\mathrm{c}} \pm 1.85$ \\
$\mathbf{7 0} \% \mathrm{~J}: \mathbf{3 0} \% \mathrm{C}$ & $5.40^{\mathrm{ab}} \pm 1.64$ & $4.35^{\mathrm{b}} \pm 1.93$ & $4.40^{\mathrm{b}} \pm 1.98$ & $4.70^{\mathrm{a}} \pm 1.84$ \\
$\mathbf{3 0 \% J : 7 0 \% C}$ & $5.00^{\mathrm{b}} \pm 1.52$ & $4.45^{\mathrm{a}} \pm 1.61$ & $4.35^{\mathrm{bc}} \pm 1.60$ & $4.40^{\mathrm{c}} \pm 1.93$ \\
\hline
\end{tabular}

Values with the same superscript on the same column are not significantly different $(p>0.05)$ from each other. 50\% J:50\%C=50\%jackfruit juice: $50 \%$ cashew juice; $70 \% \mathrm{~J}: 30 \% \mathrm{C}=70 \%$ jackfruit juice:

$30 \%$ cashew juice; $30 \% \mathrm{~J}: 70 \% \mathrm{C}=30 \%$ jackfruit juice: $70 \%$ cashew juice

of cashew juice was significantly higher than that of jackfruit juice. The higher moisture value observed in cashew fruit juice than that of jackfruit juice could be due to difference in their consistency. When compared to other studies, the moisture found in all the samples in this present study were higher than $89.5 \%$ reported for ripe paw-paw, $84 \%$ for pineapple, and $82 \%$ for sour sop juices (Akubor, 2007), but fell within values (93.3 - 94.7\%) reported for Cola parchycarpa and Cola lepidota juice respectively (Okudu et al., 2015). The high moisture values founding in the products could be attributable to the freshness and maturity of the fruits used (PamplonaRoger, 2006); moisture content of a fruit is said to be a function of its quality (Adepoju and Adenije, 2008). Crude protein value of jackfruit was significantly higher than that of cashew fruit juice. When compared to juice of other fruits, the protein contents of jackfruit juice and cashew juice $(1.32 \% ; 1.08 \%$ respectively) were higher than those of orange juice $(0.78 \%)$, water melon juice $(0.51 \%)$ (Nwakocha and Akobundu, 2013). The protein values found in the products, though low when combined with those in foods considered not good sources of protein could be cumulatively important. The crude fat, carbohydrate and energy values of the products were generally low. These results were not surprising, because studies have shown that most fruits are poor sources of crude fat, carbohydrate and energy (Akubor and Egbekun, 2007; Nwokocha and Akobundu, 2013). The low levels of fat, carbohydrate and energy observed in products shows that the products can serve as nourishing and refreshing pregame liquid meals for competitors.

The mineral compositions of jackfruit juice, cashew juice and those of their blends were significantly different from each other. Magnesium and iron in jackfruit juice were 3-folds and 2-folds respectively, higher than those found in cashew juice. However, calcium and sodium were found to be significantly higher in cashew juice than in jackfruit juice. It was, however noted that jackfruit juice added to cashew juice at different proportions increased the magnesium and iron values of the blends, but reduced the sodium values. This implies that developing blends mixtures could actually improve nutrient composition of products. When compared with other similar works, calcium and magnesium in all the products were higher than the ones reported for pineapple juice $(2.00 \mathrm{mg} / 100 \mathrm{~g}, 1.10 \mathrm{mg} / 100 \mathrm{~g}$ respectively) by Akubor (2007) and $17.4 \mathrm{mg} / 100 \mathrm{~g}$ reported for calcium in Spondias mombin juice. The magnesium found in this study was however lower than $398.0 \mathrm{mg} / 100 \mathrm{~g}$ reported for Spondias mombin juice (Akubor and Egbekun, 2007). The iron and sodium values found in this study fell within values reported for pineapple and sour sop juices (Akubor, 2007). Calcium is an important element in the body. It plays an important role in the health of bones, as well as regulation ob blood pressure, improvement of serum lipid profile, prevention of stroke and skeletal growth or development (Champagne, 2008).

Jackfruit and cashew juices are rich sources of vitamin $C$, but poor sources of $\beta$-carotene and vitamin $E$. The vitamin $C$ recommended daily intake (RDI) for children aged $4-8$ years is $25 \mathrm{~g} /$ day (Wardlaw and Hampl, 2007). This implies that consuming $8 \mathrm{ml}$ of cashew juice and $20 \mathrm{ml}$ of jackfruit juice by children within the age group of 4-8 years can supply their vitamin C daily requirements. Consuming jackfruit juice and cashew juice will enhance the iron (Fe) status of individuals, particularly in developing countries where most people depend on plants for their iron source (FNB, 2000).

Of all the three (3) antinutrients analyzed in the products, alkaloid was found to be the least. Phytate was found to be higher in jackfruit juice, while tannin was higher in cashew juice. The toxic levels of the antinutrients analyzed have not been established (Fila et al., 2012), but the values found in this study were similar to the ones reported for water melon pulp (Fila et al., 2012) in the same study it was reported that phytic acid intake of $4-9 \mathrm{mg} / 100 \mathrm{~g}$ decreases iron absorption by $4-5$ fold in humans. Fortunately, the phytate in this study is 
below that quantity.

The result of sensory attributes of the products on Table 5 showed that in terms of colour, taste, and flavor, $100 \%$ cashew juice was more acceptable than 100\% jackfruit juice. The preference of cashew juice to jackfruit juice could be because individuals are more used to cashew than jackfruit. It however interesting to note that making blends from the two products enhances the acceptability of jackfruit juice.

\section{CONCLUSION}

The major components of the products were moisture, carbohydrate and protein. Though calcium and sodium were found to be significantly higher in cashew juice than in jackfruit juice but both Jackfruit and cashew juices are rich sources of vitamin $C$, but poor sources of $\beta$-carotene and vitamin $\mathrm{E}$. It was noted that jackfruit juice added to cashew juice at different proportions increased the magnesium and iron values of the blends, but reduced the sodium values. The result also showed that making blends from cashew and jackfruit juices enhances acceptability of the products.

\section{REFERENCES}

Adepoju OT, Adeniji PO(2008). Nutrient composition, antinutritional factors and contribution of naitive pear (Dacryoides edulis) pulp to nutrient intake of consumers. Nig. J. Nutr. Sci. 29: Pp15-21.

Akinwale TO(2000). Cashew apple juice: Its use in fortifying the nutritional quality of some tropical fruits. European food Res. Technol. Pp 21:205-207.

Akubor $\mathrm{PI}(2007)$. Physicochemical and sensory properties of a beverage prepared from pineapple and sour sop juice blends. Nig. J. Nutr. Sci. 28: 201-208.

Akubor PI, Egbekum MK(2007). Physiocochemical and properties of a beverage prepared from pineapple and sour sop juice blends. J. Nutr.Sci.28: 201-208.

Burkill HM(1997). The useful plants of West Tropical Africa. Royal Botanic Gardens, Kew. 4(2): 160-161.

Champagne, C.M. (2008). Magnesium in hypertension, cardiovascular disease, metabolic syndrome, and other conditions: a review. Nutr. Clin. Pract. 23: 142-151.

Craig W, Beck L(1999). Phytochemicals: health protective effects. Can J. Diet Pract. Res. 60:78-84.

Eke-Ejiofor J, Owuno $F(2013)$. The physic-chemical and sensory properties of jackfruit (Artocarpus heterophyllus) jam. Int'l J. Nut Food Sci. 2:149-152.

Fila WO, Johnson JT, Edem PO, Odey MO, Edem VS, Ujong UP, Eteng $\mathrm{OE}(2012)$. Comparative anti-nutrient assessment of pulp, seed and rind of rambutan (Nephelium lappaceum). Scholars Res. Library.5151-5156.

Food and Nutrition Board (2000). Institute of Medicine. Dietary Reference Intakes for Vitamin C, Vitamin E, Selenium and carotenoids. Washington DC. National Academy Press.

Hart AD, Obinna-Echem PC, Azubuike CU, Philip OC(2007). Fruit and vegetables consumption pattern of students in Rivers state Uni. of Sci. and Tech. (RSUST), Port Harcourt, Nig. J. Nutr. Sci. 28(1):81-89.

Haque $M A(2010)$. Jackfruit: Botany production technology and researchin Bangladesh Jahanara Haque Publisher. 291 Darka Road Mymensingh. P.143.

Liu $\mathrm{RH}(2003)$. Health benefits of fruits and vegetables are from additive and synergistic combinations of phytochemicals. Am. J. Clin. Nutr. 78(3)5175-5205.

Mukprasirt A, Sajjaanantakul K(2004). Physico-chemical properties of flour and starch from jackfruit seed. Int'l. J. Food Sci. Technol. 39(3): 271-6.

Okudu HO, Ene-obong HN, Asumugha VU(2015). The chemical and sensory properties of juice developed from two varieties of Monkey kola (Cola parchycarpa, Cola lepidota). African J. Food Sci. Technol. 6(5):149-155.

Pamplona-Roger, G.D. (2008) Encyclopedia of Foods and their healing power. In: Umeh,

A.S. and Nwadialu,M.A.(2010). Production and proximate analysis of jam (food

spread) prepared from Cola pachycarpa JHER 13: 152-158.

Pillia R, Santha $P(2008)$. The world cashew industry (Rafain Pillia Foundation, Kollam). Nm. https://en.wikipedia.org/wiki/cashew.

Pollack, S.L. (2001). "Consumer demand for fruits and vegetables: the US example." Changing structure of global food consumption and trade. Agriculture and trade report. WRS-01-1. Regmi ed. Pp 49-54.

Rahman MA, Nahar N, Mian AJ, Mos-Huzzman M(1999). Variation of carbohydrate composition of two forms of fruit from jack tree (Artocarpus heterophyllus L) with maturity and climatic conditions. Food chem.. 65:91-97.

Smaddar HM(1985). Jackfruit. In: T.K. Bose and S.K. Mishra (eds). Fruits of India: Tropical and Subtropical. Naya Prokash/Csalcutta, India. Pp 638-649.

Unites States Dietary Alllowance (USDA) (2000). Nutrition and your health: dietary guidelines for Americans. Home and Garden Bull. 232, USDA, Washington DC. Accessed January 20th 2013, from www.usda.gov/cnpp.

Wardlaw GM, Hampl JS(2007). Perspectives in nutrition. $7^{\text {th }}$ ed.New York McGraw Hill. Pp 54-244.

Wargovich $M J(2000)$. Anticancer properties of fruits and vegetables. Hort. Science. 35:573- 575.

Williams IO, Edet AJ, Agiang MA, Lawal OO(2009). Fruits and vegetable intake pattern and Body Mass Index (BMI) of Post graduate Students in the University of Calabar, Nigeria. Nig. J. Nutr. Sci.30(2):43-49. 